\title{
Critical collaborative research: focus on the meaning of collaboration and on mediational tools
}

\section{Pesquisa crítica de colaboração: foco no significado de colaboração e nas ferramentas mediacionais}

Maria Cecília Camargo Magalhães*

Sueli Salles Fidalgo**

Pontifícia Universidade Católica de São Paulo

ABSTRACT: This text aims at discussing the concept of collaboration based on Applied Linguistics (MAGALHÃES, 1990, 1994, 2007) and on a socio-culturalhistorical perspective - SCHAT (VYGOTSKY, 1934, LEONTIEV, 1977). Situated within a critical framework, collaboration is first focused from its methodological viewpoint, and later by its socio-historical and political empowering characteristics. The text shows examples from four different historical moments of the construction of the concept of collaboration.

KEYWORDS: collaboration; critical research of collaboration; social cultural historical activity theory (SCHAT).

RESUMO: Este texto tem por objetivo discutir o conceito de colaboração com base na Linguística Aplicada (MAGALHÂES, 1990, 1994, 2007) e em uma perspectiva sócio-histórico-cultural-TASHC (VYGOTSKY, 1934, LEONTIEV, 1977). Situada em um quadro crítico, a colaboração é enfocada, em primeiro lugar, por seu viés metodológico e, em seguida, por sua característica de empoderamento a partir das relações sócio-históricas e políticas. O texto traz exemplos de quatro momentos de construção do conceito de colaboração.

PALAVRAS-CHAVE: colaboração; pesquisa crítica de colaboração; teoria da atividade sócio-histórico-cultural (TASCH).

* cicamaga@gmail.com

**ssfidalgo@terra.com.br 
This paper discusses the role of collaborative research in creating contexts for critical learning and development. More specifically, we firstly analyze the concept of collaboration in the interventionist research that our research groups are conducting in Brazilian public schools so as to examine the theoretical-methodological choices we (the researchers) have made throughout the years whilst working to understand - transform the unacceptable conditions of Brazilian deprived communities through education. Secondly, we look at the effectiveness of different kinds of linguistic tools - used by teacher educators - especially those undertaking their Master (MS) or Doctoral (DO) courses and learning how to ensure the creation of a locus for collaborative construction of critical creative knowledge to take place (critical reflection). In so doing, we investigate the paths taken in our collaborative work to establish loci where practices can be evaluated and re-organized, allowing participants (including researchers) to review the social-cultural and political forces (VYGOTSKY, 1934) that underlie their choices and sometimes prevent them from seeing pre-determined situations that they impose themselves by validating a priori social conditions and situations.

For this paper, data were collected from theses and dissertations completed by the researchers, most of which were doing their postgraduate courses on Applied Linguistics at the Postgraduate Program in Applied Linguistics and Language Studies. ${ }^{1}$ At the time of their project development, most researchers attended the public schools where the project was carried out on a voluntary basis, as teacher educators since the teachers, who work within rather deprived teaching situations, have little ongoing teacher education possibilities. Working as teacher educators on a voluntary basis is part of the requirement for students and professionals who wish to carry out their investigations as members of our research groups. ${ }^{2}$ By making this requirement, we hope to help to establish a collaborative space with the school rather than be involved in creating new (in)form(ation) for the schools.

The paper is organized to firstly define our understanding of intervention, since we have realized that there is a rather judgmental atmosphere towards the word intervention. We will then analyze the concept of collaboration in its connection to the critical reflection, arguing that (1) it is the former that allows

\footnotetext{
${ }^{1}$ Pontifical Catholic University of São Paulo.

${ }^{2}$ LACE - Language in Activities in School Contexts; and ILCAE - Language Inclusion in Scenarios of Educational Activities.
} 
for the latter to occur, and not vice-versa as has been implied in many discussions; (2) being critical has often been interpreted as the same as criticizing others, when it actually means working in the realm of us or we, rather than on the I-plus-the-other perspective; (3) collaborative work does not embrace a dualistic view of knowledge construction - rather it is the transformation of the whole (environment, group, etc.) that is at stake, since changes are inevitable. Apart from that, we look at creativity showing that it results from collaborative work in the instrument-and-result view of knowledge production proposed by Vygotsky.

The third aspect discussed in this paper will be a history of the concept of collaboration as investigated by Magalhães in teacher and researcher education programs in Brazil over the years. We argue that Magalhães and her research groups have been delving on the search for mediational tools that can be considered collaborative, rather than cooperative or even persuasive - topdown strategies that instead of creating a locus for empowerment of all involved, tend to see knowledge construction as a way to enable (or empower) others - itself a top-down perspective for the term $(s) /$ process.

In linguistic terms, our analysis will focus on the idea of the quality of intervention, discussing the concepts of sense and meaning (VYGOTSKY), authoritative as opposed to internally persuasive discourses (BAKHTIN, 1981, p. 342-348), and the quality of questions (BROOKFIELD; PRESKILL, 1999)

\section{Intervention Research and Education}

We call intervention research the type of work and investigation we develop in schools with educators in continuing education programs. Our focus in such contexts is to challenge practices and speech, focusing on social and cultural issues that historically have organized school (as non-academic environments) and universities (as knowledge production environments). This organization has repeatedly placed the former at the receiving end of knowledge produced by the latter. We therefore question the roles attributed or taken by participants in the program and within the school.

As a research model, in this investigation all participants negotiate meanings by questioning each other's individual senses about teachinglearning, classroom discourse, division of work (roles) in classroom practices, as related to the needs of specific school contexts (i.e., students, teachers, communities' needs), and to the objects that are used to carry out the task all too complex, as many researchers have discussed (e.g; HARGREAVES, 
1994; MAGALHÃES; FIDALGO, 2007; MCLAREN; GIROUX, 2000, etc). Its complexity exists mainly for two reasons: it involves different individual senses and beliefs, and requires the questioning of socio-cultural issues that historically have organized the uses of language and the division of labor and their political meaning, as pointed out by Signorini (2006). Along the same lines, one can say that one of the main egalitarian principles is that of equal consideration of interests. To us, joint consideration of different interests and needs of all involved is key to intervention projects.

Our basis here is Vygotsky's discussion of method (1934), which, as discussed by Newman \& Holzman (1993), introduced a new concept of method as dialectical and "activity-based rather than knowledge / epistemologybased". As they pointed out, method is to be "practiced" instead of "applied". In their words: " $[\mathrm{k}]$ nowledge is not separated from the activity of practicing method... Practicing method creates the object of Knowledge simultaneously with creating the tool of which that knowledge might be known." (p. 52)

Vygotsky himself was based on the Marxist frame - historical-dialectical materialism (MARX; ENGELS,1845-1846, p.17), focusing on "real individuals, their actions and the material conditions of their lives - considering at the same time the conditions that they find and the ones that they create by means of their own actions." Therefore, the emphasis is placed on keeping theory (knowledge) and practice (action) together for the development of human beings (praxis). In other words, "History is no longer a collection of lifeless facts (empiricism) or the action of imaginary subjects (idealism)" (Ibid).

Thus, intervention research, for us, is a key term for the critical research paradigm that aims at creating a context for participants to understand their actions and those of their colleagues and students, as well as the interests they serve. Instead of an authoritative and individualist frame for research, it is collaborative, and aims at creating the space for collective empowerment by creating a locus in which participants may learn new ways to organize language as well as cultural artifacts that shape their actions.

\section{Collaboration}

In intervention research, collaboration is another crucial concept, one that deals with establishing trust between participants - bringing them together to share meanings and produce knowledge by working in complementary ways. In this sense, establishing collaboration is of vital importance to create contexts in which research participants may take risks to establish conflicts and 
contradictions; critically debate concepts, values, ideas and visions and to creatively produce new ones (JOHN-STEINER, 2000).

Collaboration is seen as a process of shared evaluation and reorganization of practices, mediated by language, in activities that involve all the participants of a discussion. It is organized in ways that allow all the different participants to have possibilities to talk; question each other's senses attributed to theoretical concepts, ask for clarification, and report descriptions of concrete cases to explain their ideas or to relate theory and practice.

Therefore, collaborating involves participants' responsibility in risktaking during discussions to contribute to meaning production, to criticize and take the criticism of others as a tool for reasoning and growing. By involving all participants in shared negotiation toward political questioning of school actions based on social-cultural and historical considerations, collaborative work might, as discussed by John-Steiner (2000), overcome limitations, individualism and alienation that organize most of schools environments. In fact, as we have noticed, it is usually difficult for participants to understand the relationships between educational and political issues involved in their actions as well as in students' learning and development, since investigating the political forces that socio-historically shape the discourses and practices within schools is not something valued in educational premises.

Collaboration, therefore, does not mean there will be no contradictions and conflicts between those who take part in the debates. In fact, based on the theoretical issues put forth here, we take it that it is precisely by stressing and analyzing contradictions and conflicts that we might understand participants' (researchers' included) senses, and might be able to negotiate new production of meaning. For us, collaboration allows all voices to be heard, but more than that, it allows participants to question each others' senses and share the production of new (or newly-transformed) knowledge.

However, it is important to say that, collaborative contexts may be a "rather uncomfortable zone of action" (JOHN-STEINER, 2000, p. 82), especially when we initiate research. This is due to the fact that, usually, the focus of work in school contexts is on individual practices. By and large, social, historical, cultural and political issues are hardly considered in problem-solving (or problem challenging) discussions. Also, the discourse organized around argumentation - as a type of textual organization that can be taught-learnt is not usual in school contexts. Therefore, teachers, as well as researchers, may not be familiar with questioning or with being questioned. Much to the 
contrary, they are familiar with criticizing and being criticized as synonyms for experiencing critical reflection and critical thinking. In other words, most participants in school contexts have historically and continuously seen critical as value-laden assessment. To us, the problem lies in the assumption that an individual context-based organization might lead teachers to think that, when they are challenged, it is their individual knowledge and practices that is being questioned.

In this sense, as stated by John-Steiner (2000) and by Moran and JohnSteiner (2003), collaborative contexts always involve emotional intensity, which may cause participants to resist. To us, the analysis of materialized linguistic tools reveals how participants' voices interact; how social-and-historicallybound contradictions, and resulting conflicts are used for learning and development, as well as for social transformations. So, it is important to have linguistic categories to foster challenge and re-organization to analyze the arising issues - since language may be an instrument to exert, as well as to share power as discussed by Bakhtinian and Voloshinovian theoretical frame.

Where we stand, in Applied Linguistics, many authors have also questioned the concept of critical that seems to prevail. Pennycook (2001, p. 7), for example, states that

[w] hile the sense of critical thinking (...) attempts almost by definition to remain isolated from political questions, from issues of power, disparity, difference, or desire, the sense of critical that I want to make central to critical applied linguistics is one that takes these as the sine qua non of our work.

As Liberali (2006) argues, introducing transformations in the social, cultural and political conditions of thinking and acting in schools involves creating a locus for participants to learn how to look at, and organize language to analyze the issues at stake. In other words, researchers may sometimes have to provide teachers with tools to work with linguistic-discursive organizations to base their actions in specific situations. By and large, the researcher may need to work with the other participants the necessary language that will enable them to hold an egalitarian discussion. Being equal in rights means acknowledging each one's needs. Indeed, teachers learning how to organize language to understand their practices and to reflect critically about them have shown a transformation of the individualistic senses of what being a teacher and what being a student means in the models that have historically based 
school culture (e.g.: LIBERALI, 1999; MAGALHĀES; CELANI, 2002; LESSA, 2003)

In contexts thus developed, creativity is possible, and is jointly built in the constant attempts to both recognize and solve problems, complementarily. Creativity therefore, thrives in collaborative environments, as Moran and JohnSteiner (2003, p. 82) put it. By contrast, it is hindered when the research design gathers people with different social-cultural-historical conceptual background (including political and ethical values) in the same context, but with little or no time for complementarity to emerge.

Creativity process builds on the externalization of emotions, imagination, concepts and the varied meanings and sense of words as they are synthesized and transformed into creative products.

Understanding this concept of collaboration - that encompasses the ideas of creativity, intervention (but not from the top-down - I plus the other - type), complementarity, trust, critically listening to the other and to the self (without bringing value-laden judgments, but with a view for development) - is crucial, yet extremely complex in theory, let alone in practice. This can be seen in the data that we analyze in this paper.

\section{A history of the concept of collaboration}

Collaboration is a term that has been discussed over the years by several authors (BREDO; FEINBERG, 1982; BRAY et al., 2000). In Brazil, when Magalhães started to discuss the term, it was still a novelty, in 1990. The past nineteen years have been a search for concepts that may support the building of collaboration. As stated elsewhere (MAGALHÃES; FIDALGO, 2007), the collaborative perspective must be seen in two directions. Firstly, one must look at the concept itself - as opposed to cooperation, persuasion, etc. Secondly, it is a methodological frame that requires specific (linguistic) behavior, as stated above. In both cases, it is extremely complex, as we have pointed out before, and difficult for everyone, but mostly for postgraduate students to understand (in the doing) how to establish a "we" context for joint discussion.

We have discussed some concepts that base our view of collaborative work for critical-reflective education today. However, a historical point of view is necessary to see how the concept has been understood over the years. Collaboration is a concept that is being (re-)organized as research projects are developed, challenges are faced and creativity is brought to the spotlight. 
We have divided the next section into four moments, but it is necessary to point out that there is no clear cut between these moments as far as the relationship between time and conceptual development is concerned. As readers will easily see, in the process of re-shaping ideas, the members of the research groups have often gone back and forth in reshaping their individual senses of what was being discussed.

\section{First Moment}

Initially, collaboration was seen (MAGALHÃES, 1990) as an almost synonym of cooperation - in the sense that people work together, but do not, necessarily, negotiate points of view in order to achieve consensus (FLORIO; WALSH, 1981). Rather, they seek acceptance of each others' views - which is not the same as negotiating and sharing power and values to jointly produce new meanings. Though the focus had already been set on practical reflection (SCHÖN, 1987), methodologically speaking, the work developed was founded on the collaborative ethnographic paradigm (GITLIN et al., 1988), which was an attempt to move from ethnography (more individualistic) to participants' joint construction (accepting the other as partner and not as a sole research subject). Ethnographic work - despite Magalhães' focus on collaboration - proved, in the end, to be a locus in which (1) the teacher-participant was reluctant to collaborate, and protective of the practices that $s /$ he had used for years, and (2) the researcher juggled between the search for the right words and forms of collaboration establishment and an analysis of the other's behaviors and beliefs - in a process in which the first (i.e the teacher's resistance) led to further search (i.e., the researcher's fluctuation). As Magalhães argues (1990, p. 209):

[ $t$ ]he results of the study indicate that four dimensions of the situation are central to the development of collaboration between the teacher and the researcher. These dimensions are: (1) sharing information, (2) autonomy, (3) gathering and considering data to be shared, (4) raising questions.

Because the last dimension was conflict-bound, and because school contexts are not traditionally seen as spaces in which the teacher will be challenged, this aspect might have represented the greatest difficulty in the establishment of a collaborative perspective - in 1990 as today.

Data was analyzed based on Erickson (1986) - discrepant analysis and Glaser and Strauss (1967) - constant comparison - all within ethnographic 
frame of analysis. What was lacking in this outline was a definition and implementation of critical reasoning - and how this would be linguistically materialized in order to re-organize practice and theory. An example of the analysis using constant comparison can be seen in excerpt $1,{ }^{3}$ below, and an example of discrepant analysis can be seen in excerpt 2 .

\section{Excerpt 1 (MAGALHĀES, 1990, p. 77)}

Through a process of constant comparison and contrast, the data were sorted under the categories. During this process of constantly comparing and contrasting, new categories were created, others were joined, and others were eliminated or de-emphasized and patterns emerged. For example, the focus of Vera' 's [the teacher] instruction on decoding was understood from the data collected during the initial meetings and observations. However, decoding as a means to facilitate comprehension was learned only after the first interview, on the third week.

Excerpt 2 (MAGALHÃES, 1990, p. 78)

The data were reviewed for an examination and understanding of these cases. For example, during the first phase of the study, the researcher made the assertion that Vera occasionally provided Doris [a student] less time to come to a successful answer because of her belief about the student's inattentive behavior and lack of trying. Searching for disconfirming information, the researcher realized that Vera sometimes behaved like that with other students as well (author's emphasis).

\section{Second Moment}

The next move in the search for collaboration aroused from the need for a critical paradigm in the teaching-learning and teacher education programs (KEMMIS, 1987; GITLIN et al., 1988). This led to the view of critical collaboration rather than collaborative ethnography. Within this framework, the main concern was with the language that constitutes and is constituted by the zone of proximal development - seen as a zone of conflict in which people

\footnotetext{
${ }^{3}$ All excerpts were taken from works previously concluded, and may seem out of context here. However, their use in this paper is merely to illustrate (1) how the concept of collaboration was understood and dealt with, and (2) the type of data analysis that led to or emphasized that understanding.
} 
re-organize their reasoning with the support of others. Key concepts in this moment were turn-taking, negotiation, lexical choices, and the types of linguistic actions - questions, assertions, etc. (MAGALHÃES, 1994). Data were analyzed with a view to check the types of interactions that the linguistic choices would allow for. Excerpt 3 shows an example of this analysis.

\section{Excerpt 3 (MAGALHÃES, 1994, p. 201-202)}

C: What did you notice?

V: In general, I noticed I need to work on reading. When I saw the film, I realized I need to emphasize reading a lot because in writing they're OK. Isn't that so?

C: Hum.

$\mathrm{V}: \quad[\ldots]$ You see, Gina, she is copying almost everything. Her handwriting is $\mathrm{OK}$, reading is a great problem.

C: $[\ldots]$ Well, when you choose an activity you have a purpose in mind, don't you?

V: [...] Hum, hum

C: When you watched the film, did you realize what they were actually doing? Did you feel you reached your aim? For instance, the activities you used...

Vania's answer revealed she was analyzing her teaching and her comprehension of it based on traditional views of literacy development in first grade - reading as decoding and writing as copying - and students' difficulties with the written language as a problem within them. However, my second prompt revealed Vania's conflict motivated by her awareness of her difficulty in reaching her students, of her lack of control over her teaching, and all her dissatisfaction with this situation.

V: Well, I do not know if it is the right method, but I feel a great consistency is missing. Some days I did not know what to do.

The focus on Vygotskian studies led to a re-organization of the view on the collaborator's actions - for the teachers to understand their own standpoints and political views. There was an instrument missing in this research organization, and this was seen to be the reflective sessions - loci for argumentation to reconstitute both the researcher and the other participants (MAGALHÂES, 1998, p. 200). According to the author

\footnotetext{
${ }^{4}$ For reasons of confidentiality, participants' names are all fictitious throughout this paper.
} 
In this context, teachers, based on the types of actions for reflection proposed by Smyth (1992), work with the teacher educator in a larger group and/or with their peers in dyads when either analysing an anonymous lesson, or a colleague's or even a lesson from each of the dyad's participants.

This research path shows linguistic mediational tools that enable the exploring of the frame of collaboration for critical research and for critical reflection. As discussed by Liberali (2002), the linguistic mediational tools can be seen in the following actions:

$\Rightarrow$ describing: by use of concrete verbs; first person of speech for teacher-student if the person reporting is comfortable with the discussion of their own actions; and/or use of third person if they need more distance from their own action; as well as little or no use of opinion expressions;

$\Rightarrow$ informing: by use of expressions for providing explanations, technical vocabulary (which refers to theories);

$\Rightarrow$ confronting: by use of opinion expressions;

$\Rightarrow$ reconstructing: by use of future perfect, action verbs and verbs of "saying".

In the example below, one can see that these tools allowed for the concern to be situated in the collaboration, though still as an instrument-forresult. The excerpt selected was of the moment of informing. Interacting participants are state school teachers in the final year of a continuing program of teacher education who are practicing the frame they have learnt as part of a reflective process.

Excerpt 4 (MAGALHÃES, 2007, p. 210)

C13: What type of knowledge do you think was the focus of this lesson?

B13: I think I wanted something like this: I started with listening and worked a little on the structure of the English language, but my real objective was the oral part to finalise, performing a role-play, a dialogue, so there was a whole process. The lesson didn't finish, it was ended.

C14: (...) but then you can continue...

(...)

C15: do this in another lesson... 
B 15: yes, it was as I said before, in the beginning I tried to get them to participate more. (...)

C16: But why do you think this happened?

B16: Because giving everything ready for the student instead of getting answers from them is a habit. I think it is something that teachers do, because I, even though we have formed an image of language, we still can't really do things that way, we explain what it is, but then we see ourselves doing something different.

Linguistic choices made when organizing questions that could provide explanations and reasons for choices reveal teachers' internalization of the reflective process, though this is still based on reproducing the actions expected in critical reflection - regardless of their level of understanding or effectively being able to pursue this type of reflection. By looking at data from this period, we can see that agents either followed a script - therefore avoiding the establishment of contradictions and the creation conflicting situations - or clearly got involved in conflicts that they often saw as personal rather than a means for re-organizing thought. In other words, we often saw that as a result of the emphasis on critical reflection, many students began to understand critical reasoning as a means to criticize the actions of others - restoring, by use of cooperative and persuasive devices disguised collaborative tools, the topdown use of language that we have already argued against. In other words, the focus was reinstated as being on the "I plus you", rather than the "we". This attitude revealed the difficulty in understanding actions taken by all participants as socially-historically-contextually situated.

\section{Third Moment}

The turning point for our research groups was an immersion in the socio discursive interactionism (BRONCKART, 1997), in which we first envisaged the strong connection of language (Bakhtinian Cycle), developmental psychology (VYGOTSKY, 1934) and Critical Theory - namely the role of linguistic tools in critical theory-(HABERMAS, 1985). Within this frame, critical reflection was seen as in need for a critical-reflective-thought-organizing type of language, by means of which, the agent takes control of their own political standpoints and of their ethical perspectives (MAGALHÃES; FIDALGO, 2007). Analysis carried out in this period included concepts such as: context of production, thematic content, types of discourse, prototype sequences, utterance 
elements (modalization, positioning and deitic concord), textualization mechanisms (coherence and cohesion devices).

As discussed by Fidalgo (2006), the context of production, besides allowing us to see the physical space per se, allowed us to see the social roles taken by interlocutors - allowing for the emergence of issues of power to be viewed. As concerns the thematic content or textual referents, we were able to see the information contained in each text and therefore, constructed by each one in what Habermas (1985) has named the three worlds of action validation (objective, social and subjective). These three worlds allowed us to initially see the representations (later discussed by us as sense and meaning, based on VYGOTSKY) that were present in each participants' utterances. Besides these tools, we also used the type of discourse so as to verify the extent to which each participant is implicated in the discussion in which they take place. Bronckart and Machado (2004, p.149) state that, depending on the type of discourse used, it is possible to see the different effects of proximity, subjectivity masking and indication of distance between interlocutors. In our search for linguistic tools, we also came across Bronckart's concept of sequenciality (argumentative, descriptive, narrative sequences, and so on). According to the author, these are modes of language planning. Finally, we have the concepts of utterance elements - divided into utterance responsibility (deitic concord) and voices, plus modalization (BRONCKART, 1997).

The extract below, from Fidalgo's dissertation (2006), reveals how modalization can show the underlying principles of a school director who was interviewed.

\section{Excerpt 5 (FIDALGO, 2006)}

\section{TABLE 1}

Data analysis: modalization

\begin{tabular}{|c|c|c|c|}
\hline Deontic & Pragmatic & Psychological & Epistemic \\
\hline $\begin{array}{l}\text { C63: }(. . .) \text { they } \\
\text { need to promote } \\
\text { guidance, }(. . .) ; \\
\text { they have to } \\
\text { organize a course. }\end{array}$ & $\begin{array}{l}\text { C11: Otherwise we } \\
\text { are going to send } \\
\text { the student to this } \\
\text { regular class, and he } \\
\text { will arrive there and } \\
\text { will be unattended } \\
\text { because he will not be } \\
\text { able to do anything. }\end{array}$ & $\begin{array}{l}\text { C13(...) They say: } \\
\text { "We are in no } \\
\text { conditions to } \\
\text { receive this student" } \\
\text { and they reject } \\
\text { the student. }\end{array}$ & $\begin{array}{l}\text { C6: (...) Actually, } \\
\text { the student comes } \\
\text { here to be prepared } \\
\text { to face the regular } \\
\text { class. }\end{array}$ \\
\hline
\end{tabular}


This excerpt shows that the school principal assesses the state government as not fulfilling their part of the deal in educational inclusion; thinks that the student needs a period of adaptation prior to being included in the regular classroom; and is unable to discuss the professional possibilities (or lack thereof) in other schools (since, after all, she has said that the government has not provided them with continuing education).

\section{Current Moment}

Though still using the above stated analytical frame, we have encompassed other forms of analysis (e.g., conversational analysis). This is necessary because no matter what advances have been made in understanding and using collaboration for critical reasoning, collaborative work is still rather complex. In broad terms, it is framed by socio-cultural-historical activity theory -SCHAT - (VYGOTSKY, 1934; LEONTIEV, 1977; ENGESTRÖM, 2003) in all its complexity. In specific terms, it encompasses the type of language that allows for critical reflection and creativity. We have to look at object collaborative and creative production and labor division - both interwoven along the process of research conduction. In terms of object production, we look at the process that enables concepts of sense and meaning (VYGOTSKY) to come to action. The focus is on the Activity jointly conducted. In terms of division of labor it is to authoritative as opposed to internally persuasive discourses (BAKHTIN, 1981, p. 342-348) that we need to turn an eye. Both are intrinsically and unavoidably connected by the use of assertions and types of questions (BROOKFIELD; PRESKILL, 1999) that come to play in a discussion and reveal how participants act to listen to each other, to react to each others' speeches and to provide spaces to think and to elaborate on the others' ideas. In other words to create a mutual zone of proximal development (VYGOTSKY, 1930).

The example below, taken from Magalhães (2007) shows how internally persuasive discourses act for the joint production of knowledge about a project designed by P1 for the Acting for a Citizen School project. Here, P1 presents her school project to teachers from other state schools. Besides P1, participants included the researcher (R1) and other teachers (Ps, Px), as well as another researcher and ten teachers. 


\section{Excerpt 6 (MAGALHÃES, 2007)}

P1 the objective... the text actually is:: the stories are...comic book stories... this is the intention, isn't it? Actually... to entertain... but also to indirectly teach, because in some of the stories they are always teaching something, aren't they? Something ... we... ahn:: and Chico Bento (and his) character is part of this group ... (Teacher describes her school Project - to work with a comic book - Turma da Mônica - because the protagonists always teach something).

Ps Turma da Mônica...( a member of the same group completes to clarify which group the teacher had been talking about)

P1 da Mônica... (we have) Ceboli:::nha... Magali::: don't we? Mô::nica... Cascão... each one has their own characteristics... Magali eats too much, right? eats... eats... eats... and doesn't put on weight...we have Cebolinha... that speaks "incollectly" ... so each one has their own characteristics and actually we work by making those who are reading can notice these differences and starts to accept them... (the teacher describes the protagonists diversity in the chosen comic book to make the group's point of choosing the story to work with citizenship education).

Px: Cascão doesn't like showering (a teacher establishes a contradiction in working with a character who does not shower to discuss citizenship)...

P1 Cascão does not shower... but he is actually always talking about keeping the place clean (...) (the presenter solves the conflict establishing a confrontation between Cascão's bad habits and his concern with the environment).

As we can see, the challenges faced by P1 in her presentation allow her to re-state her understanding of the work without, however, falling into the trap of taking a purely defensive position.

\section{Work discussion}

We now turn to the discussion of data collected. As stated before, we will analyze work developed in collaborative theses and dissertation along the years, showing how the understanding of the concept of collaboration was reorganized, and how it was understood by MA, DO students and other members of the research groups along these eighteen years of discussion. We shall analyze this section as the previous, i.e, in four moments. 
First Moment. Hardly any student concluded their theses in this view. This work was solely developed by Magalhães in her Doctoral dissertation. When the collaborative work was initiated in Brazil, it quickly advanced to the second moment, or to a moment in which one could find aspects of both the first and the second moments.

Excerpt 7 (MAGALHÃES, 1990)

\section{TABLE 2}

Focus of data comprehension: ethnographic contradiction

\begin{tabular}{|c|c|}
\hline \multicolumn{2}{|r|}{ Proposed participant observation guidelines } \\
\hline Questions: & $\begin{array}{l}\text { 1. What kind of opportunities are created in classrooms for the children to } \\
\text { help them to develop effective reading strategies? } \\
\text { 2. What kind of activities are emphasized? } \\
\text { 3. Do all the children have equal opportunities to participate in classroom } \\
\text { activities? } \\
\text { 4. In what ways does the teacher / researcher make clear to the children the } \\
\text { reasoning they are supposed to engage in? } \\
\text { 5. What kind of materials are used? }\end{array}$ \\
\hline Purpose 2: & $\begin{array}{l}\text { To focus on the opportunities the teacher and the researcher create for the } \\
\text { children to become task-involved. }\end{array}$ \\
\hline Questions: & $\begin{array}{l}\text { 1. What kind of opportunities does the teacher/researcher create for the } \\
\text { children to become motivated to learn and perform? } \\
\text { 2. In what ways is learning emphasized? } \\
\text { 3. In what way is the children's active participation emphasized? } \\
\text { 4. In what way is the risk level of classroom instruction deemphasized? } \\
\text { 5. In what way are cooperation and acceptance emphasized? }\end{array}$ \\
\hline
\end{tabular}

One can see the focus on cooperation, though the aim is to achieve collaboration. The underlined words show that the researcher's role is to "observe" the school environment, yet at the same time, contradicting this ethnographic focus, she aims to intervene with a view to transform. Still, this view to transform is of the other. In other words, collaborative work was not jointly designed and implemented.

Second Moment. The second type of analysis was based on conversational analysis to establish the interaction patterns that might allow for the transformation of others (the researched participants). As the excerpt below 
demonstrates, at times, the focus was stronger on using language to enable reflectivity than on unveiling the patterns of collaborative work.

\section{Excerpt 8 (ROMERO, 1998)}

Comparison between Moments 1 (...) and 2 (...) shows a small though significant - difference in terms of the function choices both from the part of the coordinator [researcher] and the teacher. In moment 2, as one can see from the table below, the coordinator uses: (a) less commands, (b) more inquiries and more contradictions.

TABLE 3

Researcher's speech functions: comparison of moments

\begin{tabular}{l|c|c}
\hline Speech functions & First moment & Second moment \\
\hline Declarative & $40,8 \%$ & $54,9 \%$ \\
Command & $30,9 \%$ & $9,5 \%$ \\
Inquiry & $15,5 \%$ & $22,4 \%$ \\
Reiteration & $6,6 \%$ & $7,1 \%$ \\
Reply & $5,3 \%$ & $2,7 \%$ \\
Contradiction & $0,7 \%$ & $3,2 \%$ \\
\hline
\end{tabular}

As stated before, at this time, the group did not adhere to a specific linguistic framework with which to analyze data. Romero (1998), for example, uses Halliday's Systemic Functional Analysis as an attempt to find the linguistic instrument that would lead to reflectivity.

However, as one can see from the second excerpt below, this is still a moment in which I plus you was emphasized.

Excerpt 9 (ROMERO, 1998)

TABLE 4

Teacher's speech functions: comparison of moments

\begin{tabular}{l|c|c}
\hline Speech functions & First moment & Second moment \\
\hline Declarative & $32,6 \%$ & $41,5 \%$ \\
Command & $20,5 \%$ & $27,6 \%$ \\
Inquiry & $17,7 \%$ & $19,8 \%$ \\
Reiteration & $16,7 \%$ & $3,3 \%$ \\
Reply & $9,4 \%$ & $3,3 \%$ \\
Contradiction & $1,6 \%$ & $3,1 \%$ \\
\hline
\end{tabular}


What is shown here is that whilst the researcher was able to decrease her power-driven participation, the teacher was increasing her share of power. Nonetheless, the mere quantity of moments does not show the broader political, as well as socio-historical-cultural issues that are at stake. At the same time, looking at the production of speech acts places discussion at the individual level, rather than the collaborative or joint (therefore, creative) development.

Third Moment. In this period, data reveals that, although the focus is primarily on language and its relationship in the re-construction of knowledge, the collaborative work per se is solely a research frame. Our main concern was on critical reflective teaching-learning, and collaboration was the means by which to achieve it (tool-for-result). Data from Liberali's Doctoral research (1999) illustrates both the linguistic concern and the collaboration as a toolfor-result, i.e, critical reflective learning.

Excerpt 10 (LIBERALI, 1999):

TABLE 5

Questions $\mathrm{X}$ analyses

\begin{tabular}{|c|c|}
\hline Research Questions & Analyses \\
\hline $\begin{array}{l}\text { What type of discourses are developed } \\
\text { in the diaries? [reflective diaries] }\end{array}$ & Types of discourse \\
\hline $\begin{array}{l}\text { What sequencial prototypes are } \\
\text { developed? }\end{array}$ & $\begin{array}{l}\text { Sequence types [textual organization } \\
\text { that frame genres] }\end{array}$ \\
\hline $\begin{array}{l}\text { What is the relation between the sequences } \\
\text { and discourse types found, and the forms } \\
\text { of reflective action? }\end{array}$ & $\begin{array}{l}\text { Relationship between types of discourse } \\
\text { and sequences grouping; } \\
\text { Analysis of the language action found } \\
\text { in diaries. }\end{array}$ \\
\hline
\end{tabular}

As can be seen above, there is a strong concern with linguistic analysis as a means for understanding the work carried out in teacher education programs - locus of this research. There is also a strong focus on the process of change - revealed by the use of 'are developed'. Still, the concern was on the reflective action, since at the time, the group still believed that collaboration was a means to achieve critical reflection. Although most theses provided definitions of collaboration, this term was not analyzed per se. The next excerpt, however, shows that the group is moving forward in the search 
for other linguistic and organizational basis with which to understand critical reflection.

\section{Excerpt 11 (LIBERALI, 1999):}

At the time of data collection and initial analyses, I was involved with the concepts of reflection which, though discussing critical reasoning, did not provide solid support for the work developed (...). Thus the background support was based on the need to understand theory and practice.

(...) the notion of critical reflection proposed by Smyth (1992) (...) - the concreteness of the four forms of reflective actions - revealed by 'describing', 'informing', 'confronting' and 'reconstructing' - emerged as a basis for supporting not only the work developed with educators, but also the understanding of processes under construction.

It is clear, however, that the group was not giving collaborative work its due importance - since it was not part of the analysis, but a methodological frame only.

Current Moment. The intervention work we carry out today has extra concerns: clear political and ethical views of our roles as researchers and teacher educators have led us to think of collaboration as a key concept for the design of critical research - one that is creative (because it is not a means for an end, but tool-and-result) and respectful of the school needs. Transformation is still essential to any collaborative work, but transformation does not mean a priori formatted work to be applied. Transformation requires from participants that all get involved in the creation of this locus for collaborative work rather than having one group at the receiving, and another at the giving end of the continuum - a significant change in labor division.

Theoretical basis for the work currently developed is the SCHAT, as previously discussed. We look at the concrete activity to see what kinds of actions occur for collective object production. We are currently working to construct a linguistic frame that links Vygotsky's concepts of sense and meaning and Bakhtin's ideas of authoritative as opposed to internally persuasive discourses - both of which can reveal division of labor. For division of labor and responsibility, we look at qualitative rather than quantitative turn-taking analyses (KEBRAT-ORECHIONI, 1998), as excerpts 12 and 13 can reveal - in which $\mathrm{C}$ is the school coordinator and $\mathrm{P}$ is the teacher. 


\section{Excerpt 12 (MIAKOVSKY, 2008)}

TABLE 6

Turn-taking system

\begin{tabular}{|c|c|c|c|}
\hline $\begin{array}{l}\text { Rules that regulate } \\
\text { verbal interactions }\end{array}$ & & Modes & Examples \\
\hline \multirow{3}{*}{ Turn-taking management } & \multicolumn{2}{|c|}{$\begin{array}{l}\text { Implicit / explicit rules } \\
\text { super-imposition of speech }\end{array}$} & $\begin{array}{l}\text { C: Let me ask you: do they } \\
\text { have time to do the problem... }\end{array}$ \\
\hline & \multicolumn{2}{|c|}{ Super-imposition of speech } & $\begin{array}{l}\text { C: You are going to bring } \\
\text { the films... } \\
\text { P: ...the films. I'm putting } \\
\text { them on the board. } \\
\text { (both C and P spoke together) }\end{array}$ \\
\hline & \multicolumn{2}{|l|}{ Interruption } & $\begin{array}{l}\text { C:... and to rotate the film } \\
\text { (unfinished sentence) } \\
\mathrm{P}: \text { Within the group. }\end{array}$ \\
\hline $\begin{array}{l}\text { Rules that regulate the } \\
\text { structural organization of } \\
\text { interactions (opening } \\
\text { sequence, interaction, }\end{array}$ & \multicolumn{2}{|c|}{$\begin{array}{l}\text { Interchange sequence } \\
\text { questions-answers, } \\
\text { (clarification requests- } \\
\text { clarifications) }\end{array}$} & $\begin{array}{l}\text { C: Are you speaking of book } \\
\text { summary? } \\
\text { P: Yes, that's it. }\end{array}$ \\
\hline \multirow{4}{*}{$\begin{array}{l}\text { Rules that intervene in } \\
\text { the personal relationship }\end{array}$} & \multirow{4}{*}{$\begin{array}{l}\text { Vertical } \\
\text { relationship }\end{array}$} & Turn opening & $\begin{array}{l}\text { C: What is your plan for } \\
\text { this week? }\end{array}$ \\
\hline & & $\begin{array}{l}\text { High / low } \\
\text { position }\end{array}$ & $\begin{array}{l}\text { P: Oh! Ok. Now I have a } \\
\text { question here: why do they } \\
\text { use a dot in Portuguese? } \\
\text { I keep asking myself if for } \\
\text { these students who are starting } \\
\text { to work with the concept of } \\
\text { thousands... }\end{array}$ \\
\hline & & Modalization & $\begin{array}{l}\text { C: I actually do see things a } \\
\text { little this way; social activity is } \\
\text { actually [...] actually what } \\
\text { I think that we have to give } \\
\text { them is... }\end{array}$ \\
\hline & & $\begin{array}{l}\text { Positive } \\
\text { assessment }\end{array}$ & $\begin{array}{l}\mathrm{C} \text { : This is nice. And how are } \\
\text { you going to work with them? }\end{array}$ \\
\hline
\end{tabular}




\section{Excerpt 13 (MIAKOVSKY, 2008)}

The concept of collaboration, from the perspective of critical knowledge production implies the existence of conflicts and tensions that will promote other senses. However, collaborative work developed in an teaching-learning institution also foresees the possibility of taking a step back (distancing), reflecting and understanding discourses in a reflective session, a classroom and other school loci, as well as of establishing a new relationship with knowledge. The collaborative process does not establish a symmetric participation in terms of knowledge, actions or institutional power (...) (our emphasis)

To understand the critical collaborative process, we look at argumentation (LIBERALI, 2007). Besides, we also use types of questions, assertions, etc. (BROOKFIELD; PRESKILL, 1999) to see both collaboration and responsiveness taking place in knowledge production.

\section{Current and future foreseen challenges}

The history of collaboration research here presented, despite revealing constant questioning of the state of the art and linguistic frame of analysis, does not guarantee that researchers in training are able to understand the concepts well enough in order to make use of them. We believe that this happens because the collaborative framework as a basis for critical reflective teachinglearning is rather complex. Understanding each concept is quite simple. Seeing both collaboration and critical reflection intertwined - and being able to establish the part that each should play - is, however, complex. Some students can see this relationship quite well. Others find it difficult to see complementarity in construction. We understand. A number of questions arise from research that is collaboratively organized, especially for the researcher who is undertaking their first investigation, and learning how to do so as they go along. As pointed out by Fidalgo (2006, p.106),

researchers ask themselves what to do: should they take differences into account so as to negotiate consensus, or simply describe the state of the art, pretending that the presence of the researcher is not itself a situation of intervention? If we take the latter, and accept that the investigator's presence is already a kind of imposition and modifies the scenario, should s/he take a position of neutrality? Or should s/he accept that actions can never be neutral, and therefore, attempt to transform the environment and the agents? If the investigator takes the 
latter position, should s/he take a position of someone who theoretically creates knowledge to be put into practice by educators - in an experimental concept of knowledge construction - or should s/he work to create a locus in which everyone could re-organize themselves? Considering the latter position is taken, would our investigator take the position of a member of the group - who will also try to reorganize his/her own actions? If so, wouldn't this inevitably invert the theory-practice relationship that is traditionally seen in teacher education settings?

Usually, reaching the position of accepting that the relationship is no longer from theory to practice takes a long time. Novice researchers may understand this concept theoretically, but often have trouble changing their own research practices. In the continuum that they follow, they usually take one of two opposing steps: they either (1) establish a collaborative locus only, forgetting that in order for it to lead to transformation, one requires contradiction and conflict, i.e., a mutual zpd aimed at mutual development, or (2) perform a top-down establishment of contradiction and conflict aiming at transformation in an authoritative perspective - thus forgetting to establish collaboration. In both cases, they show misunderstanding of what collaboration actually means. We acknowledge this difficulty. Still, we stand by our principles and underscore the need for collaborative knowledge production, knowing well enough that, as changes are made, and as we re-organize our own thought in terms of research methodology, new challenges arise.

\section{Reference}

BAKHTIN, M. The dialogic imagination: four essays by M. M. Bakhtin. Austin, Texas: University of Texas, 1981

BAKHTIN, M.; VOLOCHÍNOV, V. N. Marxismo e filosofia da linguagem. São Paulo: Hucitec, 1929/1999.

BRAY, J.N.; LEE, J.; SMITH, L.L.; YORKS, L. Collaborative inquiry in practice: action, reflection, and making meaning. London: Sage Publications, 2000.

BREDO, E.; FEINBERB, W. Knowledge and values in social and educational research. Philadelphia: Temple University Press, 1982.

BROOKFIELD, S.D.; PRESKILL, S. Discussion as a way of teaching: tools and techniques for democratic classrooms. San Francisco: Jossey-Bass, 1999.

BRONCKART, J. P. Atividade de linguagem, textos e discursos: por um interacionismo sócio-discursivo. São Paulo: Educ, 1997/1999. 
ERICKSON, F. Qualitative methods in research on teaching. In: WITTROCK, M.C. (Ed.). Handbook of research on teaching. New York: Macmillan Publishing Co., 1986.

ENGESTRÖM, Y. Innovative learning in work teams: analyzing cycles of knowledge creation in practice. In: ENGESTRÖM, Y.; MIETTINEN, R.; PÜNAMÄKI, R-L. (Ed.). Perspectives on Activity Theory. Cambridge: Cambridge Universitary Press, 2003. p.377-404.

FIDALGO, S. S. A linguagem da inclusãolexclusão social-escolar na história, nas leis e na prática educacional. 2006. Tese (Doutorado em Linguística Aplicada) - LAEL/ PUC-SP., São Paulo, 2006.

FLORIO, S.; WALSH, M. The teacher as colleague in classroom research. In: TRUEBA, H.; GUTHRIE, G.; AU, K. (Ed.). Culture and the bilingual classroom: Studies in classroom ethnography. Rowley, MA: Newbury House, 1981. p. 87-104.

GITLIN, A.; SIEGEL,M.; BORU, K. Purpose and Method: Rethinking the Use of Ethnography by the Educational Left. In: Annual Meeting of American Educational Research Association. Proceedings... New Orleans, Lousiania, 1988. GLASER, B.; STRAUSS, A. L. The discovery of grounded theory: strategies for qualitative research. Chicago: Aldine, 1967.

HARGREAVES, A. Changing teachers, changing times. Teachers' work and culture in the postmodern age. New York: Teachers College Press, 1994.

HABERMAS, J. O Discurso filosófico da modernidade. São Paulo: Livraria Martins Fontes, 1985/2000.

JOHN-STEINER, V. Creative Collaboration. Oxford. Oxford University Press, 2000.

KEBRAT-ORECHIONI, C. Les interactiones verbales. Paris: Masson \& Armand Colin, 1998. v. I and II.

KEMMIS, S. Critical Reflection. In: WIDEEN, M.F.; ANDREWS, I. (Ed.). Staff Development for School Improvement: a focus on the teacher. New York, NY: The Elmer Press, 1987. p. 73-90.

LEONTIEV, Leontiev, A. N. Activity and Consciousness. In: Philosophy in the USSR, Problems of Dialectical Materialism. Progress Publishers. Retrieved: June, 112003 from: <http://www.marxists.org/portugues/leontiev/1978/actividade aoncienciae personalidade// introducao.htm. 1978/1997>.

LESSA, A. B. C. T. Transform[açao]: uma experiência de ensino. In: CELANI, M.A.A. Professores e formadores em mudança: relato de um processo de reflexão e transformação da prática docente. Campinas: Mercado de Letras, 2003. 
LIBERALI, F. C. O diário como ferramenta para reflexão crítica. 1998. Tese (Doutorado em Linguística Aplicada) - LAEL-PUC, São Paulo, 1998.

LIBERALI, F. C. Agente e pesquisador aprendendo na ação colaborativa. In: GIMENEZ, T. (Org.). Trajetórias na formação de professores de linguas. Londrina: Editora da UEL, 2002. p. 109-128.

LIBERALI, F. C. A formação crítica do educador na perspectiva da Lingüística Aplicada. In: ROTTAVA, L. (Org.). Ensino/Aprendizagem de Linguas: Língua Estrangeira. Ijui: UNIJUI, 2006.

MAGALHÃES, M. C. C. A Study of teacher-researcher collaboration on Chapter One Reading Instruction. Doctoral Dissertation, Virginia Polytechnic Institute \& State University, USA: College of Education, 1990.

MAGALHÃES, M. C. C. An understanding of classrooms interactions for literacy development. In: MERCER, N.; COLL, C. (Ed.). Teaching, Learning and Interaction. Madrid: Infancia y Aprendizaje, 1994.

MAGALHÃES, M. C. C. Projetos de formação contínua de educadores para uma prática crítica. The ESPecialist. São Paulo: LAEL/PUC-SP., v. 19, n. 2, p 169-184. 1998

MAGALHÃES, M. C. C. Reflective Sessions: a Tool for Teachers to Critically Comprehend Classroom Actions. In: FIDALGO, S. S.; SHIMOURA, A. S. (Org.). Pesquisa crítica de colaboração: um percurso na formação docente. São Paulo: Ductor, 2007.

MAGALHÃES, M. C. C.; CELANI, M. A. A. Continuing education: teachers' collaboration in the construction of meaning in their classroom discourse practices. Congresso Brasil 2000, UNICAMP, Campinas, São Paulo. University Press, 2002

MAGALHĀES, M. C. C.; FIDALGO, S. S. Collaboration in Continuing Teacher Education. In: ALANEN, Riikka; PÖYHÖNEN, Sari (Ed.). Language in Action: Vygotsky and Leontievian Legacy Today. Newcastle: Cambridge Scholars Publishing, 2007. p. 329-352.

MARX, K.; ENGELS, F. Feuerbach, oposição das concepçôes materialista e idealista. Retrieved: July 72007 from: <http://www.marxists.org/portugues/marx/1845/ ideologia-alema-oe/index.htm>.

MCLAREN, P.; GIROUX, H. Escrevendo nas margens: geografias de identidade, pedagogia e poder. In: McLAREN, P. (Ed.). Multiculturalismo revolucionário. Porto Alegre: Artmed, 1997/2000. p. 25-50.

MIASCOVSKY, H. W. A produção criativa na atividade sessão reflexiva em contextos de educação bilingüie. Master's thesis. Sao Paulo: LAEL/PUC-SP., 2008. 
MORAN, S.; JOHN-STEINER, V. Creativity in the Making. In: SAWYER, R.; JOHN-STEINER, V.; MORAN, S.; STERNBERG, R.; FELDMAN, D.; NAKAMURA, J.; CSIKSZENTMIHALYI, M. (Ed.). Creativity and Development. New York: Oxford University Press, 2003. p. 61-90.

NEWMAN, F..; HOLZMAN, L. Lev Vygotsky: Cientista Revolucionário. São Paulo: Edições Loyola, 1993/2002.

PENNYCOOK, A. Critical Applied Linguistics: a critical introduction. London: Lawrence Erlbaum, 2001.

ROMERO, T. A interação coordenador e professor: um processo colaborativo. Doctoral dissertation thesis. São Paulo. LAEL/PUC-SP, 1998.

SCHÖN, D. A. Educating The Reflective Practitioner. San Francisco: Jossey Bass Publishers, 1987.

SIGNORINI, I. A Questão da língua legítima na sociedade democrática: Um desafio para a Linguística Aplicada Contemporânea. In: MOITA LOPES, L. P. da (Org.). Por uma Linguística Aplicada INDISCIPLINAR. São Paulo: Parábola, 2006. p. 169-189.

SMYTH, J. Teachers work and the politics of reflection. American Educational Research Journal, v. 29, n. 2, 1992.

VYGOTSKY, L. Mind in Society. Cambridge, Massachusetts: Harvard University Press, 1930/1978.

VYGOTSKY, L. Pensamento e linguagem. São Paulo: Martins Fontes, 1934/ 1987.

Recebido em outubro de 2009. Aprovado em novembro de 2009. 